Bangladesh J. Bot. 43(2): 183-189, 2014 (September)

\title{
EFFECTS OF POTASSIUM HUMATE AND CHEMICAL FERTILIZERS ON GROWTH, YIELD AND QUALITY OF RICE (ORYZA SATIVA L.)
}

\author{
DileEP Kumar* AP Singh, P Raha ANd CM Singh \\ Department of Soil Science \& Agricultural Chemistry, Institute of Agricultural Sciences, \\ Banaras Hindu University, Varanasi-221005, India
}

Key words: Rice, Potassium humate, Chemical fertilizers, Growth, Yield and Quality

\begin{abstract}
A pot experiment was conducted in Kharif 2009 and 2010 to study the effect of potassium humate and chemical fertilizers on growth and yield attributes of rice (Oryza sativa L). Potassium humate was applied at the rate of 0,5 and $10 \mathrm{mg} / \mathrm{kg}$ soil along with 100 and 75\% recommended dose of fertilizers NPK (60, 30, 30 $\mathrm{mg} / \mathrm{kg}$ ) and $12.5 \mathrm{mg} / \mathrm{kg}$ zinc sulphate was also applied. Addition of $10 \mathrm{mg} / \mathrm{kg}$ PH along with $100 \% \mathrm{NPK}$ fertilizers and $12.5 \mathrm{mg} / \mathrm{kg}$ zinc sulphate caused significant increase in plant height, number of tillers, panicle height, panicle length, test weight, straw yield and yield of rice as compared to 100 and $75 \%$ NPK alone.
\end{abstract}

\section{Introduction}

The restoration or maintenance of soil fertility is mainly dependant on the organic matter content of the soil. The integrated use of organic sources and inorganic fertilizers is promising for achieving sustainable productivity over a longer period under intensive cropping, besides maintaining a satisfactory nutrient turnover in soil-plant system.

Application of humic acids (HA) in agriculture as fertilizer and soil conditioner was tried on limited scale. Significant impacts of humic substances (HS) on soil structure and plant growth was reported (Fong et al. 2007, El-Razek et al. 2012, Ihsanullah and Bakhashwain 2013). Humic preparations are increasingly being applied as stimulators in plant breeding. HA in proper concentrations can enhance plant and root growth (Ahmed et al. 2013). Considering the potential of HA in agriculture various commercial humic acid based products were developed and these are widely marketed. The HA products are usually available in the form of inexpensive soluble salts, referred to as potassium humate (Fong et al. 2007).

Potassium humate is a highly concentrated form of humus in the naturally occurring lignite which is the brown coal that accompanies coal deposits. It is a peat material that has not been subjected to high pressures to turn it into coal, and from this potassium humate is produced. Reports on the utilization of humic acid in cereals crops are rare. Hence the effect of humic acid along with chemical fertilizers on growth, yield and quality of rice was investigated.

\section{Material and Methods}

A two year replicated experiment during 2009 and 2010 kharif seasons was conducted in net house of the Department of Soil Science and Agricultural Chemistry, Institute of Agricultural Sciences, Banaras Hindu University, Varanasi, India to evaluate the effect of potassium humate and chemical fertilizers on growth and yield attributes of rice. The experiment was arranged in factorial completely randomized design with three replications. Potassium humate was applied in soil at the rate of 5.0 and $10.0 \mathrm{mg} / \mathrm{kg}$ soil along with 100 and $75 \%$ recommended doses of fertilizers NPK (60, 30, $30 \mathrm{mg} / \mathrm{kg}$ ) and $12.5 \mathrm{mg} / \mathrm{kg}$ zinc sulphate was also used. Bulk surface soil

*Authors for correspondence: <dileepdixit.bhu@gmail.com>. 
sample was collected from the research farm of the Institute. After collecting the soil, it was grounded and passed through $2.0 \mathrm{~mm}$ sieve and $8 \mathrm{~kg}$ of processed soil was filled in each polythene lined pot. Soil was puddled and 5 seedlings of rice (variety Malviya 36) transplanted in each pot. After establishment four plants were maintained. Potassium humate used for experimentation contained $70 \%$ humic acid and $10 \%$ potassium with $95 \%$ solubility. Soil collected from research farm for pot experiment was analysed for various physic-chemical properties. $\mathrm{pH}$ (7.9) and EC (0.211), organic carbon (0.43\%), available N (185 kg/ha, available, P (17.25 kg/ha), available K (198.85 kg/ha) and available S (10.24 kg/ha) was analysed by standard procedure. The height of plant and number of tillers was recorded at tillering, panicle initiation and harvesting stages. At physiological maturity stage, the plants were harvested and grain yield pot $^{-1}$ was recorded after harvesting of crop. All obtained data from experiment was statistically analyzed according to factorial CRD design. (Gomaz and Gomaz 1984).

\section{Result and Discussion}

Plant height was significantly higher under recommended dose of fertilizers (RDF) 100\% over $\mathrm{RDF}_{75 \%}$ during all the growth stages in both the years of experimentation (Table 1). In potassium humate treatment, application of $10 \mathrm{mg} / \mathrm{kg}$ potassium humate $\left(\mathrm{PH}_{10}\right)$ recorded maximum plant height (113.18 in first year and $116 \mathrm{~cm}$ in second year) during tillering, panicle initiation and harvesting stages of rice. Similarly HA induced stimulation of plant growth were reported by Chen and Aviad 1990 and Arancon et al. 2002). These substances can have a direct effect through absorption of humic compounds by the plant and thus affecting the enzyme activities and membrane permeability (Nardi et al. 2002). Interaction effect of potassium humate with RDF and zinc was non-significant in plant height in both seasons.

Application of potassium humate $\left(\mathrm{PH}_{10}\right)$ resulted in a significantly increase in number of tillers/pot at tillering (22.05 tillers), panicle initiation (18.91 tillers) and harvesting stage (17.95 tillers) as compared to $\mathrm{PH}_{0}$ (Table 1). It was reported that the application of humic acid increased the synthesis and activity of IAA, which played a significant role in promoting the plant growth. Mohammadipour, (2012) showed that the application of humic acid improved the plant growth parameters.

Panicle length is a very important parameter because of its association with other important yield components such as number of grains and 1000 grain weight. Potassium humate significantly affected panicle length at $\mathrm{PH}_{10}$ in both the years (Table 2). Bama and Selvakumari (2005) also reported that application of potassium humate @ $20 \mathrm{~kg} / \mathrm{ha}$ recorded higher panicle length of rice crop. Panicle length was also increased significantly following application of 12.5 $\mathrm{mg} / \mathrm{kg}$ zinc sulphate $\left(\mathrm{Zn}_{12.5}\right)$ over $0 \mathrm{mg} / \mathrm{kg}$ zinc sulphate $\left(\mathrm{Zn}_{0}\right)$ during the both the years of experimentation (Table 2). These results are in line with the findings of Maqsood et al. (1999) who reported that adequate supply of zinc to rice increased its panicle length. Interaction of potassium humate with RDF and zinc was found to be non-significant.

Application of $100 \%$ RDF recorded significantly higher 1000 grain weight over $75 \%$ RDF during both the years (Table 2). Significant effect of NPK fertilizer levels on 1000 grain weight was also reported by Ali et al. (2000). Among the humic acid treatments, $\left(\mathrm{PH}_{10}\right)$ produced highest mean value of 1000 grain weight $19.22 \mathrm{~g}$ during first year and $20.42 \mathrm{~g}$ during second year whereas lowest value was obtained by treatment $\mathrm{PH}_{0}$. Patil et al. (2011) reported that yield characters were significantly affected by application of potassium humate. The interaction effect of RDF and potassium humate was found to be non-significant on test weight during both the years of experimentation. 


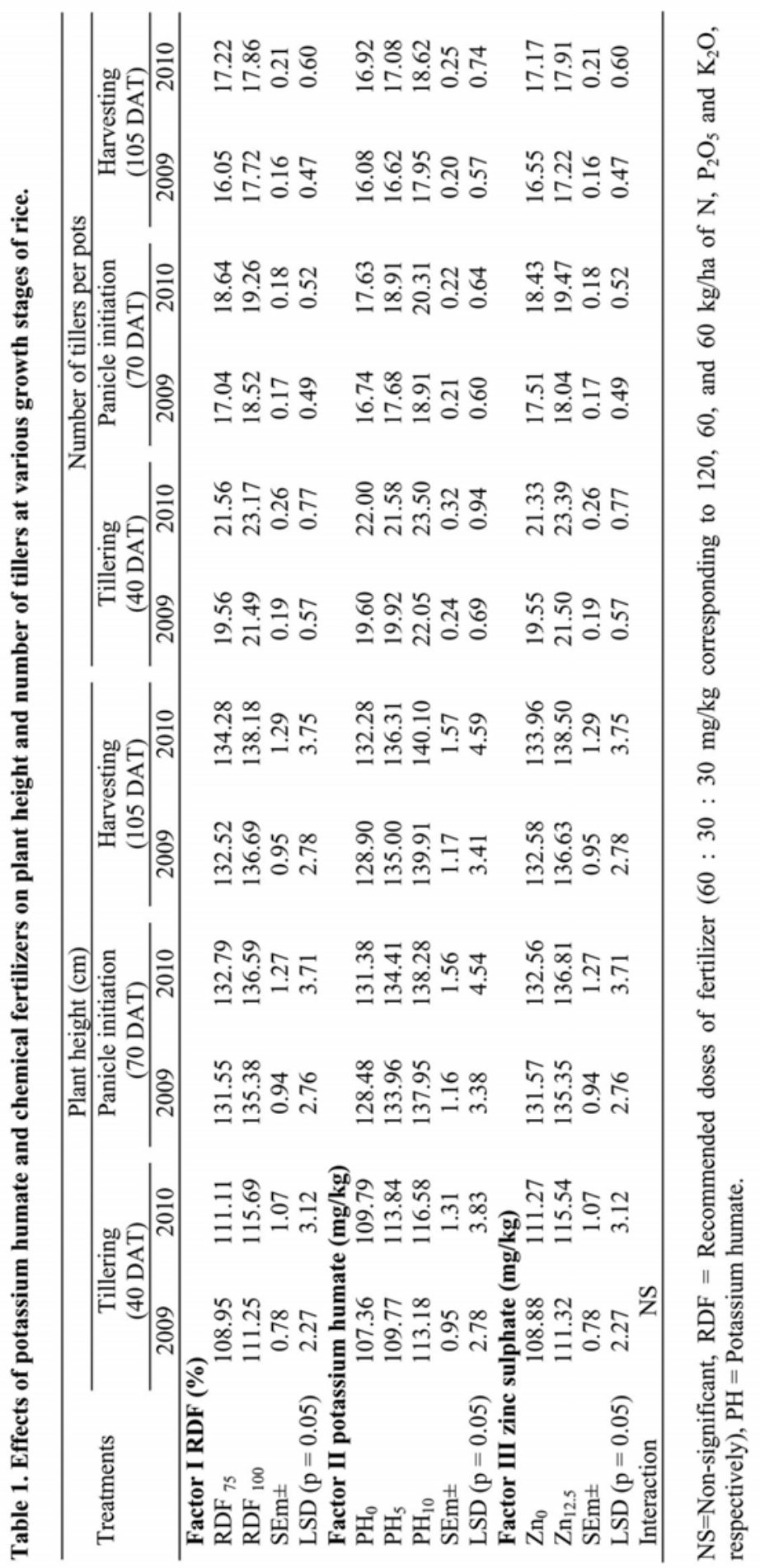




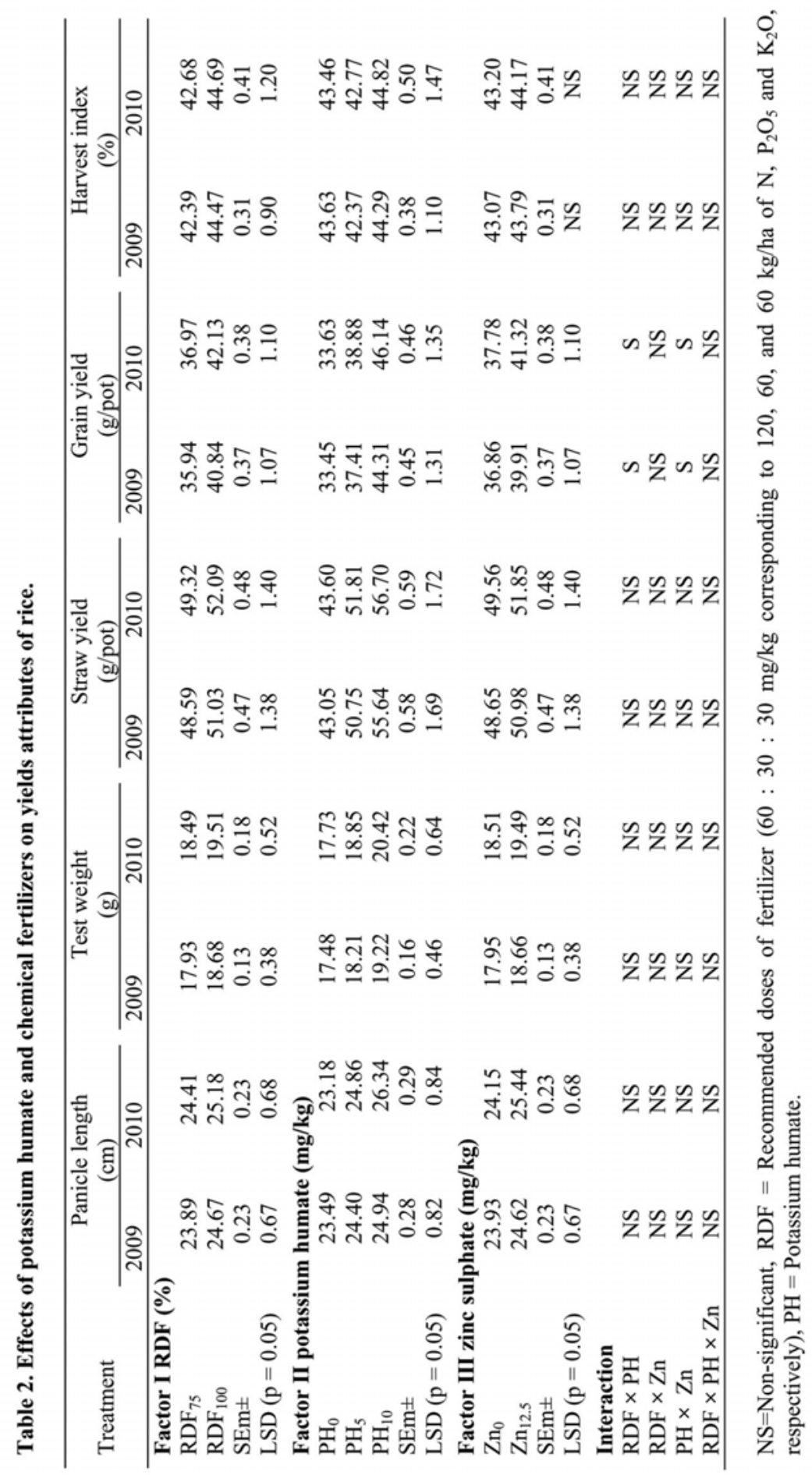




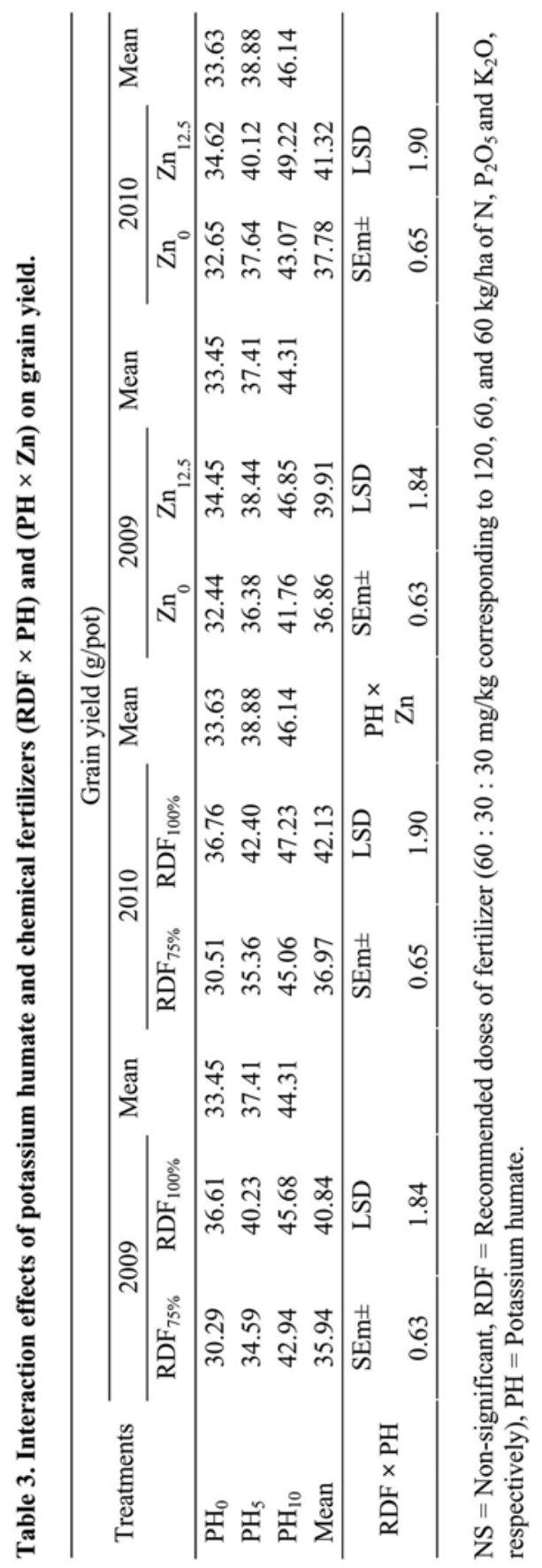


In case of application of different rates of humic acid and chemical fertilizers, in rice $\mathrm{RDF}_{100 \%}$ produced significantly higher mean value of grain yield over $\mathrm{RDF}_{75 \%}$ (Table 2). Among the potassium humate treatments, the highest grain yield $(44.31 \mathrm{mg} / \mathrm{kg})$ was obtained from treatment $\mathrm{PH}_{10}$ which was significantly higher than $\mathrm{PH}_{5}$ and $\mathrm{PH}_{0}$. Treatment $\mathrm{PH}_{10}$ produced $37.19 \%$ higher grain yield over $\mathrm{PH}_{0}$ and $18.67 \%$ higher over $\mathrm{PH}_{5}$. Interaction effect of potassium humate with RDF and zinc was also found to be significant (Table 3). The highest rice grain yield (45.68 g/pot) was obtained from treatment $\mathrm{PH}_{10} \times \mathrm{RDF}_{100 \%}$ fallowed by $\mathrm{PH}_{10} \times \mathrm{Zn}_{12.5}(46.85 \mathrm{~g} / \mathrm{pot})$ whereas lowest value of grain yield $(30.29 \mathrm{~g} / \mathrm{pot})$ was found with the treatment $\mathrm{PH}_{0} \times \mathrm{RDF}_{75 \%}$ fallowed by $\mathrm{PH}_{0} \times \mathrm{Zn}_{0}$ (32.44 g/pot) (Table 3). Khan and Mir (2002) stated that humic acids derived from Pakistani lignite had a beneficial effect on the growth and yield of wheat. A number of workers have reported that humic amendments increased yields of tomato, cotton, and grape vines (Brownell et al. 1987).

Results embodying this paper suggest that humic acid extracted from the huge reserves of lignitic coal in India can be used as a low cost natural fertilizer for improving yields of crop.

\section{Acknowledgement}

The first author (DK) wishes to thank Banaras Hindu University for financial assistance and providing necessary facilities.

\section{References}

Ahmed AHH, Darwish E, Hamoda SAF and Alobaidy MG 2013. Effect of putrescine and humic acid on growth, yield and chemical composition of cotton plants grown under saline soil conditions. AmericanEurasian J. Agri. Envi. Sci. 13: 479-497.

Ali A, Choudhry MA, Malik MA, Ahmad R and Saifullah 2000. Effect of various doses of nitrogen on the growth and yield of two wheat (Triticum aestivum L.) cultivars. Pakistan J. Biol. Sci. 3: 1004-1005.

Arancon NQ, Lee S, Edwards CA and Atiyeh R 2002. Effects of humic acids derived from cattle, food and paper-waste vermicomposts on growth of greenhouse plants.Pedobiol. 47: 741-744.

Bama KS, and Selvakumari G 2005. Effect of humic acid and fertilisers on yield and nutrition of rice in alfisol. J. Ecobiol. 17(1): 41-47.

Brownell JR, Nordstrom G, Marihart J and Jorgensen G 1987 Crop responses from two new leonardite extracts. Sci. Total Environ. 62: 491-499.

Chen Y and Aviad T 1990. Effects of humic substances on plant growth. In: MacCarthy, P., Clapp, C.E., Malcolm, R.L. and Bloom, P.R. (Eds.), Humic Substances in Soil and Crop Sciences: Selected Readings, ASA and SSSA, Madison, 161-186.

El-Razek EA, Abd-Allah ASE, Saleh MMS 2012. Yield and fruit quality of Florida Prince peach trees as affected by foliar and soil applications of humic acid. J. Applied Sci. Res. 8(12): 5724-5729.

Fong SS, Seng L, and Mat HB 2007. Reuse of Nitric Acid in the Oxidative Pretreatment Step for Preparation of Humic Acids from Low Rank Coal of Mukah, Sarawak. J. Braz. Chem. Soc. 18: 41-46.

Gomez KA and Gomez AA 1984. Statistical procedures for agriculture research. Wiley Press, New York.

Ihsanullah Daur and Bakhashwain AA 2013 Effect of humic acid on growth and quality of maize fodder production. Pakistan J. Bot. 45: 21-25.

Khan AR, and Mir S 2002. Plant growth stimulation of lignite humic acid, part II: Effect oflignite-derived ammonium humate on wheat (Triticumaestivum V.) crop using different levelsof phosphate fertilizer. Pakistan J. Indus. Sci. Res. 45: 273-276.

Lowry OH, Rosebrough NJ Farr A and Land Rordall RJ 1951. J. Bio. Chem. 193-265. Madison, Wisconsin, USA. pp. 501-538

Maqsood M, Akbar M, Yousaf N, Mehmood MT and Ahmad S 1999 Effect of different rate of N, P and K combinations on yield and components of yield of wheat, Int. J. Agri. Biol. 1: 359-361. 
Mohammadipour E, Golchin A, Mohammadi J, Negahdar N, Zarchini M 2012. Improvement fresh weight and aerial part yield of marigold (Calendula officinalis L.) by humic acid. Annals of Biol. Res. 3: 11, 5178-5180.

Nardi S, Pizzeghello D, Muscolo A and Vianello A 2002. Physiological effects of humic substances on higher plants. Soil Biol. Biochem. 34: 1527-1536.

Patil RB, Kadam AS, Wadje SS 2011. Role of potassium humate on growth and yield of soybean and black gram. Int, J. Pharma Biol. Sci. 2: 1, B-246.

Yemm EW, Willis AJ 1954. The estimation of carbohydrates in plant extract by anthrone. Biochem. J. 57: 508-514.

(Manuscript received on 10 September, 2013; revised on 9 April, 2014) 